\title{
Awareness and Usage of UGC-Infonet Digital Library Consortium among Faculty Members of State Universities in Tamil Nadu: A Survey
}

\author{
S. Thanuskodi \\ Library \& Information Science Wing, Directorate of Distance Education, Annamalai University, 608002, Annamalai Nagar \\ thanuskodi_s@yahoo.com
}

\begin{abstract}
The increasing price of electronic journals, indexing and abstracting databases along with the traditional published print subscriptions has forced library community to explore alternative means of subscription. The emergence of library a very promising development in this direction. The Phenomenon of consortia or group of libraries maintaining information resources together has become very common these days, In India, during last few years we witnessed many consortia based subscription. When library consortiums are formed, the existing environment about users' preferences and difficulties need to be studied. Initiating such studies would enable to incorporate the findings as the major input in consortium formation. A questionnaire based survey found that $94.40 \%$ of the science faculty members were aware about the UGC-Infonet Digital Library Consortium whereas only $86.99 \%$ of social science faculty members were aware about the availability of UGC-Infonet Digital Library Consortium. The study reveals that most of the respondents $75.35 \%$ use the UGC-Infonet resources for the purpose of research work.
\end{abstract}

Keywords UGC-Infonet, Internet, e-resources, CD-ROM, e-journals, e-books, web sites, Information and Communication Technolgy.

\section{Introduction}

India has significant advantages in the $21^{\text {st }}$ Century knowledge race. It has a large higher Education sector - the third largest in the world in student numbers, after China and the United States. Next to Chinna, India is the most populated country in the world. Naturally there is much rush and competition in every filed. So rush to technical and higher education has increased as scope for social science and science has become lesser and lesser due to lack of reforms and up gradation the course structure and materials according to the developments of the world. Also, qualification in higher education gives added advantage to face successfully competition in the job market. A well equipped and well managed library is the foundation of modern educational structure. The importance of library in higher education can be appreciated, properly and precisely only if we try to understand the changing concepts of education of the present day. "Education and Library services are twin sisters and one cannot live apart from the other." It means that library is the chief instrument so far perfected for accumulating and using

* Corresponding author:

thanuskodi_s@yahoo.com (S. Thanuskodi)

Published online at http://journal.sapub.org/ijis

Copyright (C) 2012 Scientific \& Academic Publishing. All Rights Reserved man's intellectual heritage. And any formal education at all levels can be conducted more effectively and efficiently only with a well equipped libraries.

Today, libraries are surrounded by networked data that is connected to a vast ocean of Internet-based services. Moreover, electronic resources relevant to the professions are developing at an unprecedented pace. Academic libraries are considered to be the nerve centres of academic institutions, and must support teaching, research, and other academic programmes. The situation in academic libraries of India is the same as that of academic libraries the world over; however, Indian libraries must provide maximum information with limited resources.

The University Grants Commission, through its novel programme. 'UGC-Infonet Digital Library Consortium' has come forward to help the university libraries, so that access to large number of scholarly online journals is made available to the user community. So far 277 universities in India are covered under the UGC-Infonet Digital Library Consortium. There are 22 universities in Tamil Nadu. The University library users are expected to make use of these valuable online resources and integrate the benefits into their academic activities and extend the frontiers of knowledge. In this context, it is important to know whether the faculty members are making use of UGC-Infonet Digital Library consortium resources, the frequency and purpose of its use, 
problems faced in using and reasons for non-use. The knowledge of these issues will, no doubt, help to plan for further improvements in user services.

\section{Library Consortia}

It is not possible for one library or information centres to hold the full stock of information resources or to procure all information, which may be in demand by its clientele. Even not a single library or information center can meet the thrust of knowledge of all the readers from its holdings. To solve this problem, library cooperation started long ago, such as interlibrary loan, document delivery, library networks, etc. At present, the more accepted system of resource sharing is called library consortia. Consortia approach is one of the many ways of maintaining cooperation and coordination among the libraries and in fact, it has emerged as the 'state of the art' in library cooperation in recent years. The aim of the consortia is to achieve what the member of the group cannot achieve individually. A consortium is said to be "a cooperative arrangement among group of institution," or "an association or society" (American Heritage Dictionary). Consortia are commonly formed to increase the purchasing power of the collaborating institutions to expand the resource availability and to offer automated services. The idea of consortium is not new. There were instances of several libraries coming together voluntarily for the mutual benefit of respective users just like cooperatives, it was the earliest stage of library cooperation. In the second stage, computerized networks come into vogue for sharing of resources. Till this period, the library resources were mainly in traditional printed format. The networks created their bibliographical databases. The users of the participating libraries could get the required documents from other libraries through document delivery services. With the advent of e-resources, the concept of consortia has been mooted mainly for acquisition of e-journals. As the resources that are procured today through the consortium are mainly e-resources, it has become possible for the users to access and download the required materials without even going through the elaborate process of inter library lending. Though library consortia have been created with narrow purpose, these can be turned into efficient instruments for sharing all types of library resource.

\section{Features of Library Consortia}

Access to resources is now considered more important than the collection building. The consortium facilitates the libraries to get the benefit of wider access to electronic resources at affordable cost and at the best terms of licenses. A consortium, with the collective strength of resources of various institutions available to it, is in a better position to resolve the problems of managing, organizing and archiving the electronic resources. Some of the major issues that address the need for consortium are:
$>$ Indian Universities are finding it hard to maintain the subscriptions even for core journals due to ever increasing cost of the journal subscriptions and also a shrinking budget.

Academic and research users can now hope to have access to their learned journal articles in electronic form.

$>\quad$ The average number of subscriptions to international journals by Indian universities is very less than the western countries.

There should be an increase in the availability of information in electronic form with more and more literature published in e-form.

$>\quad$ Reduction in the staff strength and cost savings for library budget would be useful.

$>\quad$ Greater buying and increased access to sources would be beneficial.

\section{Ugc-Infonet Digital Library Consortium}

The UGC-Infonet Digital Library Consortium was formally launched in December, 2003 by Honourable Dr. A P J Abdul Kalam, the President of India soon after providing the Internet connectivity to the universities in the year 2003 under the UGC-Infonet programme. The Consortium proved to be a recipe to university libraries which have been discontinuing subscription of scholarly journals because of "Serials Crisis". The term "serials crisis" refers to exponential and continuing increase in subscription cost of scholarly journals. The crisis is a result of rise in cost of journals much faster than the rate of inflation, increase in number of journals and the paucity of funds available to the libraries

The Consortium provides current as well as archival access to more than $7000+$ core and peer-reviewed journals and 10 bibliographic databases from 26 publishers and aggregators in different disciplines. The programme has been implemented in phased manner. In the first phase that began in 2004, access to e-resources was provided to 50 universities who had Internet connectivity under the UGC-Infonet Connectivity programme of the UGC. In the second phase, 50 more universities were added to the programme in the year 2005. So far 277 Universities come under the purview of UGC, have been provided differential access to subscribed e-resources. These e-resources covers almost all subject disciplines including arts, humanities, social sciences, physical sciences, chemical Sciences, life sciences, computer sciences, mathematics and statistics, etc. The programme is wholly funded by the UGC and executed by the INFLIBNET (Information and Library Network) Centre, Ahmedabad.

\section{Objectives}

To know the extent of awareness and use of the UGC-Infonet Digital Library Consortium by faculty member in Tamil Nadu State Universities. 
- To find out the awareness of users' about available e-resources.

- To find out the frequency of access to internet.

- To examine the respondents' purpose of gathering e-resources

- To study the respondents' e-resource use pattern and extent of usage in their profession

- To study the respondents' satisfaction and problems in utilizing the e-resources

\section{Literature Review}

Akasawa and Ueda ${ }^{1}$ examined the usage of electronic resources by a specific academic community in Japan academic economists. The study found that only about 31 percent of the respondents used electronic journals at the time the survey was carried out, but about 75 percent of the respondents perceived this medium is of high value.

Veenapani, Singh and Devi ${ }^{2}$ conducted a study to determine the use of UGC-Infonet Digital Library Consortium by teachers and researchers, revealed that 55 percent were aware and 45 percent were not aware of the consortium. Problems faced by the users of the consortium include: ICT illiteracy frequent power cuts, slow internet speed, insufficient number of computers and problems in selection of desired titles of journals.

A survey conducted by Bhatt and $\mathrm{Joshi}^{3}$ to assess the impact of UGC-Infonet Digital Library Consortium on academic community revealed that the number of research degrees awarded in the field of social sciences, humanities, pure and applied sciences had increased significantly.

Madhusudhan ${ }^{4}$ revealed that e-journals perform an increasingly important role in research t the Department of Library and Information Science, University of Delhi where not only current e-journals are significant but electronic back runs are also required by the research scholars and students. There is an ever increasing demand for subscriptions of more e-journal titles in LIS. There also appears to be some need for training in using e-journals.

Khaiser and Pramodhini ${ }^{5}$ describe the use of e-journals and databases by the user of University of Mysore and examine the utilization and satisfaction levels of user with respect to the e-resources.

Raza and Upadhyay ${ }^{6}$ reveal that all the researchers of Aligarh Muslim University are aware about the availability of e-journals in the university and that many research scholars were consulting e-journals form their departmental labs and computer centers.

Patil and Parameshwar's ${ }^{7}$ study revealed that 62.91 percent of the faculty members expressed the need for more number of journals. Kumbar and Hadagali ${ }^{8}$ found that 64.29 percent of the faculty members needed regular training / awareness / orientation programmes for making best use of the UGC-Infonet Digital Library Consortium.

\section{Methodology}

Survey method has been adopted and a questionnaire, designed keeping in view of the objective of the study, has been used as a data collection tool. The questionnaires were personally distributed among the faculty members in all the 22 state universities. The feedback collected was tabulated and analyzed. 330 faculty members randomly selected in the science and social science faculty of Tamil Nadu State Universities. The questionnaires were distributed to the sample population of which 284 (86.06\%) have responded.

\section{Data Analysis}

Analysis of data is the ultimate step in research process. It is the link between raw data and significant results leading to conclusions. This process of analysis has to be result oriented.

Table 1. Faculty wise Distribution of Respondents

\begin{tabular}{|c|c|c|}
\hline Name of the Faculty & No. of Respondents & Percentage \\
\hline Social Science & 123 & 43.30 \\
\hline Science & 161 & 56.70 \\
\hline Total & 284 & 100.00 \\
\hline
\end{tabular}

A study of data in table-1 indicates the faculty wise distribution of respondents. It could be noted that out of the total 284 respondents, 43.30 per cent of them are social science faculty members and 56.70 per cent of them are science faculty members. It is concluded that more science faculty members followed by social science faculty members are the respondents in the study.

Table 2. Gender wise Distribution of Respondents

\begin{tabular}{|c|c|c|}
\hline Gender & No. of Respondents & Percentage \\
\hline Male & 198 & 69.71 \\
\hline Female & 86 & 30.28 \\
\hline Total & 284 & 100.00 \\
\hline
\end{tabular}

A study of data in table-2 indicates the gender distribution of respondents. It could be noted that out of the total 284 respondents, more than two thirds of the respondents $(69.71 \%)$ belong to the male group and the rest one third of them $(30.28 \%)$ are females.

\subsection{Distribution of Respondents by Designation}

Table-3 describes the distribution of respondents by designation.

Table 3. Designation wise Distribution of Respondents

\begin{tabular}{|c|c|c|}
\hline Designation & No. of Respondents & Percentage \\
\hline Professor & 56 & 19.72 \\
\hline Associate Professor & 72 & 25.35 \\
\hline Assistant Professor & 156 & 54.93 \\
\hline Total & 284 & 100.00 \\
\hline
\end{tabular}


Table 4. Faculty wise Respondents' Mode of Searching Documents in the Library

\begin{tabular}{|c|c|c|c|c|c|c|}
\hline Name of the Faculty & Library Catalogue & Library Staff & Directly Search in the Stack & Websites & Online Database & Total \\
\hline Social Science & $\begin{array}{c}7 \\
(5.69)\end{array}$ & $\begin{array}{c}19 \\
(15.45)\end{array}$ & $\begin{array}{c}29 \\
(23.57)\end{array}$ & $\begin{array}{c}26 \\
(21.14)\end{array}$ & $\begin{array}{c}42 \\
(34.15)\end{array}$ & 123 \\
\hline Science & 12 & $\begin{array}{c}43 \\
(14.28)\end{array}$ & $(21.74)$ & $\begin{array}{c}41 \\
(25.47)\end{array}$ & $\begin{array}{c}50 \\
(31.06)\end{array}$ & 161 \\
\hline \multirow{2}{*}{ Total } & 19 & $\begin{array}{c}62 \\
(14.78)\end{array}$ & $(22.54)$ & $(23.59)$ & $(32.39)$ & 284 \\
\hline
\end{tabular}

Table 5. Faculty wise Respondents' Frequency of Access to Internet

\begin{tabular}{|c|c|c|c|c|c|c|}
\hline Name of the Faculty & Daily & Weekly twice & Weekly & Once in a Fortnight & As and when required & Total \\
\hline \multirow{2}{*}{ Social Science } & 26 & 42 & 23 & 13 & 19 & $(15.46)$ \\
& $(21.14)$ & $(34.15)$ & $(18.69)$ & 123 \\
\hline \multirow{2}{*}{ Science } & 48 & 63 & 25 & 14 & 11 & $(6.84)$ \\
& $(29.81)$ & $(39.13)$ & $(15.53)$ & $(8.69)$ & 30 & 161 \\
\hline \multirow{2}{*}{ Total } & 74 & 105 & 48 & $(10.56)$ & 284 \\
\hline
\end{tabular}

A study of data in table-3 indicates the designation wise distribution of respondents. It could be noted that out of the total 284 respondents, 54.93 per cent of them belong to the Assistant Professor and 25.35 per cent of them come under the Associate Professor. In this study, 19.72 per cent of the respondents are found in the Professor. It is concluded that a more than a half of the respondents belong to the Assistant Professor.

\subsection{Information Searching Pattern}

Searching for the right information is a skill. Some studies have shown that some users tend to rely on library catalogue to find information in libraries while some others search on their own or take the help of the library staff to find out the relevant information.

Data presented in table- 4 indicate the faculty wise respondents' mode of searching documents in the library. It could be noted that majority of the social science $(34.15 \%)$ and science $(31.06 \%)$ faculty members search library documents with the help of online database. A considerable number of social science faculty members search library documents directly in the stack room. Around $25.47 \%$ of the science faculty members make use of website to search library documents. It could be seen clearly from the above discussion that social science and science faculty members mainly make use of online database to search documents in the library.

\subsection{Internet Access}

The use of e-resources partially depends on the extent of internet access. Most of electronic information resources are accessible through internet. The advocates have been asked to indicate the frequency of access to Internet.

Data presented in table- 5 indicate the faculty wise respondents' frequency of access to internet. It could be noted that majority of the social science $(34.15 \%)$ and science (36.13) faculty respondents have access to internet weekly twice. Around one third of the science faculty respondents
(29.81\%) have access to internet daily. It could be seen clearly from the above discussion that weekly twice of access to internet is quite common among the respondents of science and social science faculty members.

\subsection{Awareness about UGC-Infonet Digital Library Consortium}

Table 6. Awareness about UGC-Infonet Digital Library Consortium

\begin{tabular}{|c|c|c|}
\hline Name of the Faculty & Aware & Not Aware \\
\hline Social Science & $107(86.99 \%)$ & $16(13.01 \%)$ \\
\hline Science & $152(94.40 \%)$ & $9(5.60 \%)$ \\
\hline Total & $259(91.19 \%)$ & $25(8.81 \%)$ \\
\hline
\end{tabular}

Table-6 shows the awareness of UGC-Infonet Digital Library Consortium among the respondents available through the library. $94.40 \%$ of the science faculty members were aware about the UGC-Infonet Digital Library Consortium whereas only $86.99 \%$ of social science faculty members were aware about the availability of UGC-Infonet Digital Library Consortium. It can be seen that science faculty members are more aware about UGC-Infonet Digital Library Consortium than social science faculty members.

\subsection{Frequency of use of UGC-Infonet Digital Library Consortium}

Data presented in table-7 indicate the faculty wise respondents' frequency of UGC-Infonet Digital Library Consortium visits. It could be noted that majority of the science faculty members $(35.40 \%)$ make UGC-Infonet Digital Library Consortium visit once in a week. Majority of the social science faculty members (39.84\%) make UGC-Infonet Digital Library Consortium visit as and when required. It could be seen clearly from the above discussion that science faculty respondents mainly make UGC-Infonet Digital Library Consortium visit once in a week and social science faculty respondents make high level of UGC-Infonet Digital Library Consortium visit as and when required. 
Table 7. Frequency of use of UGC-Infonet Digital Library Consortium by faculty members

\begin{tabular}{|c|c|c|c|c|c|c|}
\hline Name of the Faculty & Daily & Weekly twice & Weekly & Once in a Fortnight & As and when required & Total \\
\hline Social Science & $\begin{array}{c}8 \\
(6.50)\end{array}$ & $\begin{array}{c}18 \\
(14.64)\end{array}$ & $\begin{array}{c}26 \\
(21.14)\end{array}$ & $\begin{array}{c}22 \\
(17.88)\end{array}$ & $\begin{array}{c}49 \\
(39.84)\end{array}$ & 123 \\
\hline Science & $\begin{array}{c}19 \\
(11.81)\end{array}$ & $\begin{array}{c}35 \\
(21.74)\end{array}$ & $\begin{array}{c}57 \\
(35.40)\end{array}$ & $\begin{array}{c}26 \\
(16.15)\end{array}$ & $\begin{array}{c}24 \\
(14.90)\end{array}$ & 161 \\
\hline \multirow{2}{*}{ Total } & 27 & $\begin{array}{c}53 \\
(18.66)\end{array}$ & $\begin{array}{c}83 \\
(29.23)\end{array}$ & $\begin{array}{c}73 \\
(25.70)\end{array}$ & 284 \\
\hline
\end{tabular}

\subsection{Purpose of Using UGC-Infonet Digital Library Consortium}

Table 8. Purpose of using UGC-Infonet Digital Library Consortium

\begin{tabular}{|c|c|c|}
\hline Purpose & Number & Percentage \\
\hline To keep abreast with the latest developments & 93 & 32.74 \\
\hline For teaching & 106 & 37.32 \\
\hline For research & 214 & 75.35 \\
\hline For guiding research students & 86 & 30.28 \\
\hline For writing books & 64 & 22.53 \\
\hline For writing research articles & 182 & 64.08 \\
\hline Others & 38 & 13.38 \\
\hline
\end{tabular}

Note: Total sample exceeds the required size since the questions are multiple choices

From the table- 8 , it is clear that most of the respondents $75.35 \%$ use the UGC-Infonet resources for the purpose of research work followed by 64.08 for writing research papers. $37.32 \%$ of respondents use the UGC-Infonet resources for teaching and $32.74 \%$ respondents for keeping up to date with the latest developments in their field of specialization. $30.28 \%$ of respondents use for guiding research students.

\subsection{Problems faced in using UGC-Infonet Digital Library Consortium}

Table 9. Problems faced by faculty members in using UGC-Infonet Digital Library Consortium

\begin{tabular}{|l|l|l|}
\hline Problems & Number & Percentage \\
\hline Lack of knowledge to use & 45 & 15.84 \\
\hline $\begin{array}{l}\text { Lack of sufficient Internet nodes in University } \\
\text { Library }\end{array}$ & 76 & 26.76 \\
\hline $\begin{array}{l}\text { Lack of accessibility to UGC-Infonet } \\
\text { E-Journal Consortium at Department Chamber }\end{array}$ & 164 & 57.74 \\
\hline Slow Internet bandwith & 78 & 27.46 \\
\hline Technical Problems & 94 & 33.09 \\
\hline Frequent Power cut & 132 & 46.47 \\
\hline Lack of relevant information sources & 67 & 23.59 \\
\hline Lack of assistance by library staff & 47 & 16.54 \\
\hline
\end{tabular}

Note: Total sample exceeds the required size since the questions are multiple choices

A study of data in table-9 indicates the problems faced by faculty members in using UGC-Infonet Digital Library Consortium. More than half of the respondents stated that lack of accessibility to UGC-Infonet E-Journal consortium at department chamber, with a nearly equal number who saw a frequent power cut while using in UGC-Infonet digital library consortium. Around one third of the respondents indicated technical problems followed by slow Internet bandwith, lack of sufficient Internet nodes in university library, lack of relevant information sources, lack of assistance by library staff and lack of knowledge to use.

\subsection{Opinion towards UGC-Infonet Digital Library Consortium Services}

Table 10. Faculty wise Respondents' Views on UGC-Infonet Digital Library Consortium Service

$\left.\begin{array}{|c|c|c|c|c|c|c|}\hline \begin{array}{c}\text { Name of the } \\ \text { Faculty }\end{array} & \text { Excellent } & \text { Good } & \begin{array}{c}\text { No } \\ \text { Opinion }\end{array} & \text { Poor } & \begin{array}{c}\text { Very } \\ \text { Poor }\end{array} & \text { Total } \\ \hline \begin{array}{c}\text { Social } \\ \text { Science }\end{array} & \begin{array}{c}19 \\ (15.45)\end{array} & \begin{array}{c}43 \\ (34.96)\end{array} & \begin{array}{c}13 \\ (10.56)\end{array} & \begin{array}{c}27 \\ (21.95)\end{array} & \begin{array}{c}21 \\ (17.08)\end{array} & 123 \\ \hline \text { Science } & \begin{array}{c}32 \\ (19.88)\end{array} & \begin{array}{c}68 \\ (42.24)\end{array} & \begin{array}{c}5 \\ (3.11)\end{array} & \begin{array}{c}23 \\ (14.28)\end{array} & \begin{array}{c}33 \\ (20.49)\end{array} & 161 \\ \hline \text { Total } & 51 & 111 & 18 & 50 & 54 & 284 \\ (17.96) & (39.08) & (6.34) & (17.61) & (19.01)\end{array}\right)$

Table-10 presents data on the faculty wise respondents' views on UGC-Infonet Digital Library Consortium services. It could be noted that nearly half of the science faculty respondents (42.24\%) and social science faculty respondents (34.96\%) observe that UGC-Infonet Digital Library Consortium services are good. Both one third of the science and social science faculty members have poor opinion about UGC-Infonet Digital Library Consortium services of the state universities in Tamil Nadu.

\section{Recommendations}

Based on the findings of the study the following recommendations are made:

- All State University libraries should take a leading role to create awareness among faculty members about the UGC-Infonet Digital Library Consortium by conducting training programmes, workshops, audio-visual presentations, demonstrations, etc., on regular basis. The university should support the library in every possible way and faculty members should cooperate in this regard.

- User education should be conducted for a small group of faculty members belonging to a single subject discipline such as mathematics, chemistry, physics, biology, economics, sociology etc. at a time so that the resources accessible under the consortium in a particular subject can be made known to the concerned faculty members and is highly focused.

- There is a need to evaluate the UGC-Infonet Consortium and include more number of journals in the consortium.

- The faculty members and research scholars should refer 
electronic journals which were published by Academic press, Kluver, Springer, etc.

- There is a need to include more number of journals in UGC-Infonet Consortium.

- Internet bandwidth should be increased

- University library should increase the number of internet nodes exclusively for faculty members.

- The faculty members should be divided on the basis of their knowledge to use the ICT for imparting user education. Those who lack knowledge to use the ICT should be given special training on computer and Internet skills.

- The faculty members and research scholars try to avoid printed version of books because these may out dated.

\section{Conclusions}

The advent of e publishing has brought a revolution in journals publication, subscription as well as access to the scholarly literature. The age of library consortia is at the doorsteps to prove the library cooperation locally, regionally, nationally and internationally. It is the one of the emerging tool kit for the maximum libraries to survive if the libraries have to provide information to their users. A large portion of faculty members in the state universities are aware about the UGC-Infonet Digital Library Consortium, but they do not know all its techniques and applications. Further, a few faculty members have no knowledge about the UGC-Infonet Digital Library Consortium and related applications. For this purpose, there is need for effective user education, to develop awareness and knowledge of the UGC-Infonet Digital Library Consortium. Further, there is need to include more number of Journals in the Consortium. Users also expected other kinds of Services along with the UGC Infonet Service. Majority of the users rated the Consortium services are good. But there is need to improve internet facility.

\section{REFERENCES}

[1] Akasawa $\mathrm{M}$ and Ueda S. On the use of electronic media by academic economics. Library and Information Science, 1998, 40, 1-27.

[2] Veenapani S, Singhg Khomdom and Devi R. Use of e-resources and UGC-Infonet consortium by the teachers and research scholars in Manipur University. In Jagadish Arora et al. (Eds) From Automation to Transformation (Ahmedabad: INFLIBNET Centre) 2008. pp. 563-568.

[3] Bhatt J and Joshi N. Impact of UGC-Infonet Digital Library Consortium to academic community: a case study of Maharaja Sayajirao University of Baroda. Proceedings of the $7^{\text {th }}$ International CALIBER-2009, Pondicherry University, Puducherry, February 25-27, 2009. pp.565-571.

[4] Madhusudhan M. Usage of UGC- Infonet e-journal by research scholars and student of the University of Delhi, Delhi: A study. Library Hi Tech, 2008, 23(3), 369-386.

[5] Khaiser N and Pramodini B. Use of e-journals and databases by the academic community of University of Mysore: a Survey. Annals of Library and Information Studies, 2007, 54, 19-22.

[6] Raza M and Upadhyay A K. Usage of e-journals by researchers in Aligarh Muslim University: A study. The International Information \& Library Review, 2006, 38, 170-179.

[7] Patil D.B and Parameshwar S, Use of electronic resources by faculty members and research scholars in Gulbarga University, Gulbarga: a Survey, SRELS Journal of Information Management, 2009, 46(1), pp.51-60.

[8] Kumbar BD and Hadagali G.S. Use of UGC-Infonet E-journals consortium by faculty members and research scholars of Karnataka University, Dharwad. SRELS Journal of Information Management, 2009, 46(1), pp.41-50. 